\title{
Design of Non Invasive Pulse Rate Detector using LabVIEW
}

\author{
Sonali Navghare \\ Research Scholar, Department of Electronics \\ Engineering \\ G.H. Raisoni College of Engineering
}

\author{
Preeti Bajaj, PhD \\ Department of Electronics Engineering \\ G.H. Raisoni College of Engineering
}

\begin{abstract}
To study the prakruti of a person, a physician has to put his three fingers on the wrist $(2 \mathrm{~cm}$ below the palm) of the individual to sense the vibrations occurring in the radial pulse in Traditional Indian Medicine (TIM). But the most predictable pulse signal acquirement instruments only captures the signal at single location which is under a set pressure, thus capturing just limited pulse analytic information. In the proposed methodology a non invasive pulse signal acquisition system has been developed depending on the virtual instrumentation technology using LabVIEW software. The system would encompass sensors and data acquisition equipment as the hardware circuitry and the signal processing system based on LabVIEW software intended for the successful recognition of diseases. The system intends to employ more compact and feasible technique for detection of radial pulse and differentiation between the three pressure points than the existing counterparts.
\end{abstract}

\section{Keywords}

Three pressure points, Traditional Indian Medicine(TIM), Pulse Data Acquisition, Signal Processing in LabVIEW.

\section{INTRODUCTION}

The pulse signal is the inclusive reflection of occurrence, pace, structure, intensity and pressure of pulse. The pulse signal is very strongly connected with ailment, which is extremely significant for the curing based on syndrome differentiation. The necessary tool for the study of pulse signal is the pulse signal acquisition device. It is real time method that can explain the information of pulse subjectively $\&$ accurately. It can also offer methodical references for reliability of pulse taking methods. With the advancement in modern signal processing technology, virtual instrument technology has improved the fresh production of medical instruments. These technologies make therapeutic instruments more supportive and reliable, followed by higher detection precision.

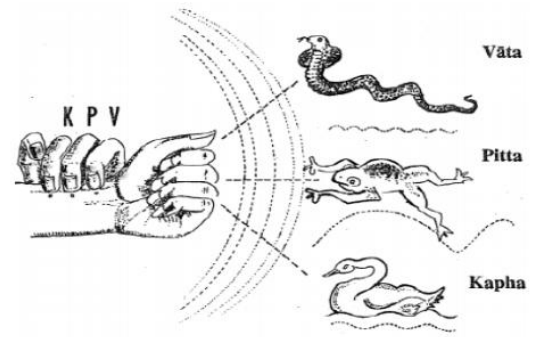

Fig. 1 Shapes of waveform of vata, pitta and kapha pulses

Human life is considered as an accumulation of three humors [1](Vata, Pitta and Kapha), seven minerals (tissues) and three vain (waste) products. Vata (Wind, Air) - Constitutes motion and desire, Pitta (Bile, Fire) - The theory of assimilation and transformation, Kapha (Mucus, Water) - Comprises stability (Fig.1). The different waveforms obtained from vata, pitta and kapha pulses have shape similar to that of movement of cobra, frog and swan respectively as shown in Fig. 1. In Traditional Indian Ayurveda (TIM) wrist pulse pressure signal analysis is used for health diagnosis. This method gives key importance to three different pulse points of wrist artery of the two hands. This approach is defined based on the pressure gesture reflection gait in human arteries which terminate into several organs.

Doshas and subdoshas are instrumental in ayurvedic pulse diagnosis. According to ayurveda the intelligence of the blood transmits information via the blood stream throughout the body. Specific combinations of the five elements; fire, water, earth, air and space form the principles, or doshas, vata, pitta and kapha. These three principles can be felt in the pulse. Vata is expressed as movement within the physiology. Pitta is experienced as heat and metabolization, and kapha is seen as structure. The specific details of every bodily function as well as how that function expresses itself within the context of the entire body can be understood by these three doshas. Maintaining a balance of the doshas according to a person's individuality is considered the basis of perfect health. Only when the doshas get out of balance will a person experience discomfort and disease.

Now-a-days the field of biomedical instruments [6], [14] uses virtual instrumentation system. More precision in the pulse rate calculations is needed as far as heart diseases are concerned. So non invasive method for pulse detection with utmost accuracy is the need of the hour and the methods should be cost efficient. The preprocessing unit is necessary for wrist pulse detection to eliminate fluctuations \& noise present in pulses. The features of irregular pulses present in the pulse series and details associated with the extraction of time related pulse features [5]. Some novel researches on subjectifying Traditional Chinese Pulse Diagnosis (TCPD) by means of some recent signal processing methods has been discussed in [3]. Researches on time domain has been carried out and the synchronizing features in frequency domain are extracted. Monitoring the pulse and the characteristic extraction of the pulse has been introduced. Furthermore wrist pulse acquisition and analysis of system is explained by the author some of which have been used in the proposed system. A more refined software and compact hardware technique has been used to resolve the pulse parameters[4]. Pulse rate inconsistency is calculated by using capacitive sensors with piezoelectric sensors. Changes in volume, time, std. deviation, frequency domain parameters are analyzed. The disease detection by means of these four parameters of pulse, has been projected in the system. 
An abridged hardware circuitry had been used for pulse exposure as given in [2]. Here a key for the pressure sensor placement has been provided by the author. Three pressures using pressure sensors are considered. Device could acquire complete multichannel pulse signals, i.e., three-channel of main signals together with the sub signals, and thus more indicative features could be extracted. In future developments, improving the degree of exactness of computerized pulse diagnosis has been projected. The sensor placement in the proposed methodology has been referred from this work.

Design and extension of an original, low-cost, non-invasive and compressed device that generates pulse pressure waveforms using Infrared sensor has been discussed in [1]. This information would prove to be a support to the Ayurvedic experts for better disease analysis. Further, the waveforms obtained from the apparatus are analyzed and parameters designed are the positive vigor and negative vigor content of the body, and the heart rate of the entity. Signal processing has been carried out in LabVIEW. The different characteristics of the pulses have been indicated in Table 1 .

Table 1: Different Characteristics of Vata, Pitta and Kapha

\begin{tabular}{|l|l|l|l|}
\hline & 1 st pulse & 2nd pulse & 3rd pulse \\
\hline Frequency & $80-95$ & $70-80$ & $50-60$ \\
\hline Location & Index & Middle & Ring \\
\hline Amplitude & Low & High & Moderate \\
\hline Regularity & Irregular & Regular & Regular \\
\hline $\begin{array}{l}\text { Temperat- } \\
\text { ure }\end{array}$ & Cold & Hot & $\begin{array}{l}\text { Warm to } \\
\text { Cool to }\end{array}$ \\
\hline Vessel Wall & $\begin{array}{l}\text { Rough, } \\
\text { hard }\end{array}$ & $\begin{array}{l}\text { Elastic, } \\
\text { flexible }\end{array}$ & $\begin{array}{l}\text { Soft, } \\
\text { thickening }\end{array}$ \\
\hline Traits & $\begin{array}{l}\text { High up, } \\
\text { strong, } \\
\text { high } \\
\text { like snake }\end{array}$ & $\begin{array}{l}\text { Rapid and } \\
\text { leaps like a } \\
\text { frog }\end{array}$ & $\begin{array}{l}\text { Deep, slow, } \\
\text { Broad like } \\
\text { swan }\end{array}$ \\
\hline
\end{tabular}

\section{Flowchart:}

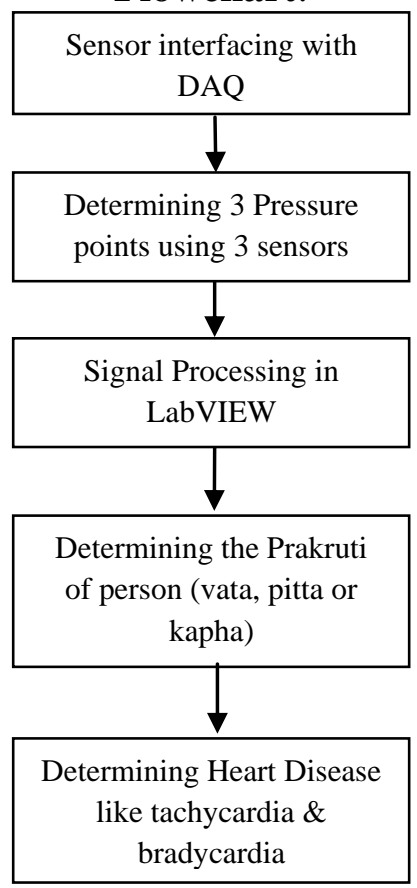

Fig.2 Flow Chart of proposed system using LabVIEW

Fig. 2 shows the basic Flow Chart of the Pulse Data Acquisition system. Force Sensitive Resistor (FSR) is used to acquire signals from arterial pulse. NI cDAQ 9174 chassis and NI 9219 Analog DAQ card is used for data acquisiion. Then the acquired data has been processed using various filters. Two parameters of the waveform have been selected viz. the frequency and the amplitude (voltage). The next step is programming the system for the prediction of prakruti considering amplitude and frequency as the key parameters. The last part is programming for the detection of tachycardia and bradycardia.

\section{HARDWARE USED:}

Fig. 3 shows the signal processing using LabVIEW. The first step for interfacing the sensors would be designing the hardware circuitry for proper functioning of sensors. The analog DAQ card has 4 slots i.e. one slot per channel starting from $\mathrm{CH} 0$ to $\mathrm{CH} 3$. For three FSRs three channels were used i.e. one channel per FSR. After making all the hardware connections the analog DAQ card has been tested in the Measurement and Automation explorer (MAX). The first step in signal processing of the acquired signals would include passing the signals from various filters. The responses from different filters have been recorded and analyzed by using separate VIs. Depending on those responses high pass filter had been chosen as an appropriate filter. Then further programming for prakruti prediction has been done using the comparators. The resultant output waveforms were observed in the front Panel VI. 


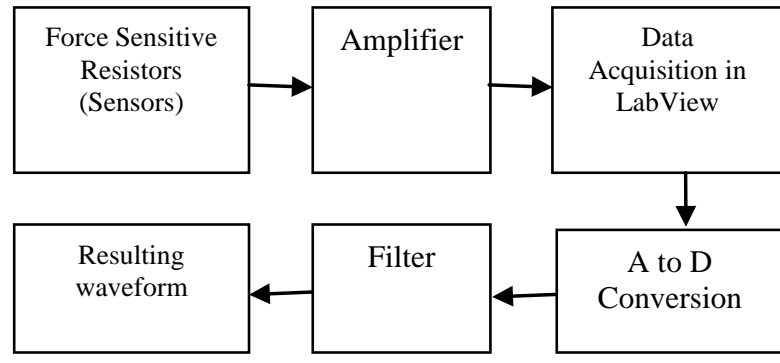

Fig. 3 Block Diagram of Signal Processing using LabVIEW

Fig. 3 shows the signal processing using LabVIEW. The first step for interfacing the sensors would be designing the hardware circuitry for proper functioning of sensors. The analog DAQ card has 4 slots i.e. one slot per channel starting from $\mathrm{CHO}$ to $\mathrm{CH} 3$. For three FSRs three channels were used i.e. one channel per FSR. After making all the hardware connections the analog DAQ card has been tested in the Measurement and Automation explorer (MAX). The first step in signal processing of the acquired signals would include passing the signals from various filters. The responses from different filters have been recorded and analyzed by using separate VIs. Depending on those responses high pass filter had been chosen as an appropriate filter. Then further programming for prakruti prediction has been done using the comparators. The resultant output waveforms were observed in the front Panel VI.

Fig.4 shows the Data Acquisition Equipment Compatible with NI LabVIEW. Compact DAQ NI 9174 Chassis and Fig.5 shows Analog DAQ card NI 9219 which is used as the main hardware.

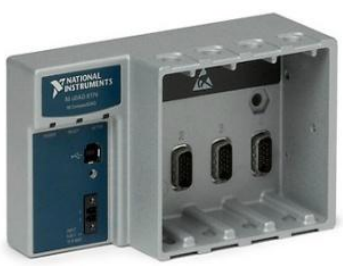

Fig.4 NI cDAQ 9174

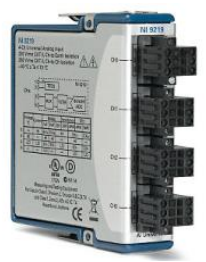

Fig.5 NI 9219
FSRs (Fig. 6) are two-wired devices which changes resistance after application of force. The FSR is used as voltage divider by connecting external resistor with it. This arrangement converts force-to-voltage. LM 358 has been used as the operational amplifier. The output is equation is as follows:

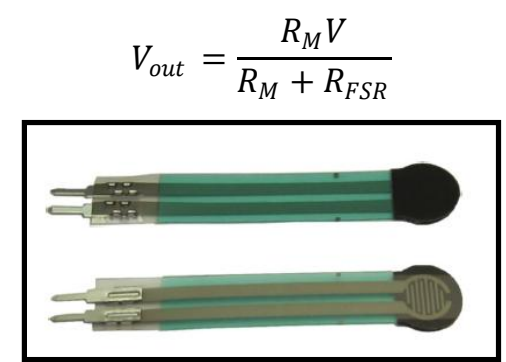

Fig.6 Force Sensitive Resistors (FSRs)

\section{RESULTS}

After the proper designing of hardware connections and software programming are done the results of the pulse rate detector are shown in the front panel of LabVIEW. The output from three different filters was acquired using 3 different VIs.
The recorded outputs of each filter were analyzed and compared and the output from the most appropriate filter is considered as the final output. The resultant waveforms are shown on the waveform charts, the predicted prakruti and the detected heart disease is shown by a particular LED.

\section{Results by using Smoothing Filters}

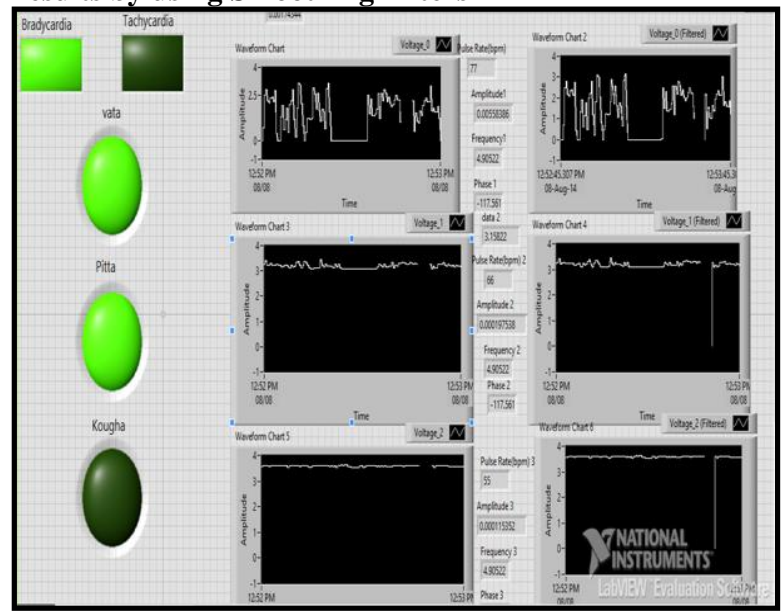

Fig. 7: Results on the Front Panel by using Smoothing Filter

The outputs from smoothing filter are shown in the Fig.7. The prakruti of the subject in the figure is vata and pitta also the person is suffering from Bradycardia. The changes in the pulse rate, the amplitude and the data acquired are shown by the numeric indicators on the front panel. This is a rectangular moving average type of filter with the half width of moving average is 1600 . The amplitude and frequency of the output voltage that were recorded in the Excel sheet is shown in the Table 2. The results in the excel sheet show the maximum and minimum voltage levels of each (kapha, vata \& pitta pulses) of the pressure points from each sensor and the minimum waveform increment.

Table 2: Results by using Smoothing Filter

\begin{tabular}{|c|c|c|c|c|}
\hline $\begin{array}{l}\text { Channel } \\
\text { vata }\end{array}$ & Minimum & Maximum & $\begin{array}{l}\text { Descriptio } \\
\text { n }\end{array}$ & $\begin{array}{l}\min \\
w f \_ \text {increm } \\
\text { ent }\end{array}$ \\
\hline $\begin{array}{l}\text { Voltage_0 } \\
\text { (Detected } \\
\text { Amplitude) }\end{array}$ & 0.00054 & 4.2 & vata & 0.00013 \\
\hline $\begin{array}{l}\text { Voltage_0 } \\
\text { (Detected } \\
\text { Frequency) }\end{array}$ & 71 & 76 & & \\
\hline $\begin{array}{l}\text { Channel } \\
\text { pitta }\end{array}$ & Minimum & Maximum & $\begin{array}{l}\text { Descriptio } \\
\text { n }\end{array}$ & $\begin{array}{l}\min \\
w f \_ \text {increm } \\
\text { ent }\end{array}$ \\
\hline $\begin{array}{l}\text { Voltage_1 } \\
\text { (Detected } \\
\text { Amplitude) }\end{array}$ & 0.00068 & 3.1 & Pitta & 0.00026 \\
\hline $\begin{array}{l}\text { Voltage_1 } \\
\text { (Detected } \\
\text { Frequency) }\end{array}$ & 63 & 68 & & \\
\hline $\begin{array}{l}\text { Channel } \\
\text { kapha }\end{array}$ & Minimum & Maximum & $\begin{array}{l}\text { Descriptio } \\
\text { n }\end{array}$ & $\begin{array}{l}\min \\
w f \_ \text {increm }\end{array}$ \\
\hline
\end{tabular}




\begin{tabular}{|l|l|l|l|l|}
\hline & & & & ent \\
\hline $\begin{array}{l}\text { Voltage_2 } \\
\text { (Detected } \\
\text { Amplitude) }\end{array}$ & 0.00075 & 3.6 & kapha & 0.00018 \\
\hline $\begin{array}{l}\text { Voltage_2 } \\
\text { (Detected } \\
\text { Frequency) }\end{array}$ & 64 & 67 & & \\
\hline
\end{tabular}

Results by using High pass Filters

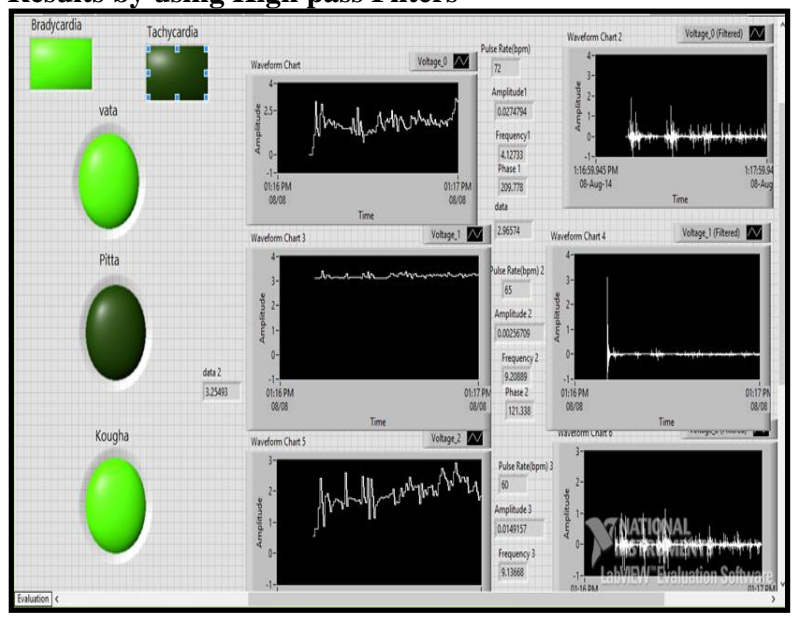

Fig. 8: Results on the Front Panel by using High Pass Filter

The outputs from High pass filter are shown in the Fig. 8. The cutoff frequency of the High pass filter is $5 \mathrm{~Hz}$. The filter type is Infinite Impulse Response (IIR) filter with Butterworth filter of $13^{\text {th }}$ order. The figure below shows the prakruti of the person i.e. vata and kapha. The person is also suffering from Bradycardia since the recorded pulse rate after one minute is less than $40 \mathrm{~Hz}$ and the amplitude variations that are recorded in the pitta waveforms are less than 0.5 Volts. The amplitude and frequency of the output voltage that were recorded in the Excel sheet is shown in the Table 3.

Table 3: Results by using High Pass Filter

\begin{tabular}{|c|c|c|c|c|}
\hline $\begin{array}{l}\text { Channel } \\
\text { vata }\end{array}$ & Minimum & Maximum & Description & $\begin{array}{l}\min \\
\text { wf_increment }\end{array}$ \\
\hline $\begin{array}{l}\text { Voltage_0 } \\
\text { (Detected } \\
\text { Amplitude) }\end{array}$ & 0.3 & 4.87 & vata & 0.18 \\
\hline $\begin{array}{l}\text { Voltage_0 } \\
\text { (Detected } \\
\text { Frequency) }\end{array}$ & 81 & 87 & & \\
\hline $\begin{array}{l}\text { Channel } \\
\text { pitta }\end{array}$ & Minimum & Maximum & Description & $\begin{array}{l}\min \\
\text { wf_increment }\end{array}$ \\
\hline $\begin{array}{l}\text { Voltage_1 } \\
\text { (Detected } \\
\text { Amplitude) }\end{array}$ & 0.4 & 3.8 & pitta & 0.2 \\
\hline $\begin{array}{l}\text { Voltage_1 } \\
\text { (Detected } \\
\text { Frequency) }\end{array}$ & 67 & 72 & & \\
\hline Channel & Minimum & Maximum & Description & $\min$ \\
\hline
\end{tabular}

\begin{tabular}{|l|l|l|l|l|}
\hline kapha & & & & wf_increment \\
\hline $\begin{array}{l}\text { Voltage_2 } \\
\text { (Detected } \\
\text { Amplitude) }\end{array}$ & 0.5 & 4.1 & kapha & 0.31 \\
\hline $\begin{array}{l}\text { Voltage_2 } \\
\text { (Detected } \\
\text { Frequency) }\end{array}$ & 61 & 68 & & \\
\hline
\end{tabular}

Results by using Low pass Filters

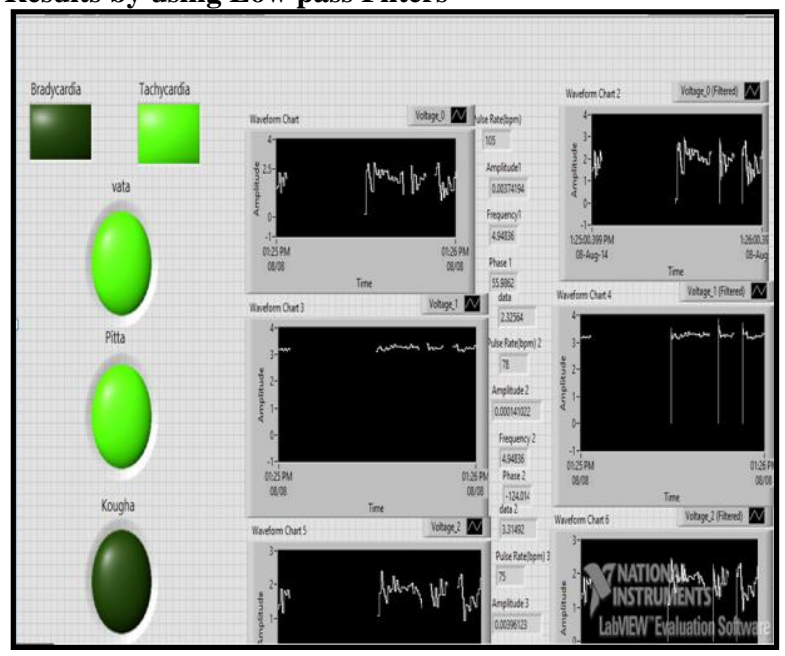

Fig. 9: Results on the Front Panel by using Low Pass Filters

The outputs from Low Pass Filter are shown in the Fig. 9. The person is also suffering from Tachycardia since the maximum frequency recorded in the excel sheet is $103 \mathrm{~Hz}$ and the minimum amplitude increment is 0.72 volts. The cutoff frequency of the Low pass filter is $500 \mathrm{~Hz}$. The filter type is Infinite Impulse Response (IIR) filter with Butterworth filter of $13^{\text {th }}$ order. The amplitude and frequency of the output voltage that were recorded in the Excel sheet is shown in the Table 4. There are two columns of waveforms in which the waveforms in the first column are the raw waveform and the waveforms in the second column are the signal processed waveforms of kapha, vata and pitta.

Table 4: Results by using Low Pass Filter

\begin{tabular}{|l|l|l|l|l|}
\hline $\begin{array}{l}\text { Channel } \\
\text { vata }\end{array}$ & Minimum & Maximum & Description & $\begin{array}{l}\text { min } \\
\text { wf_increment }\end{array}$ \\
\hline $\begin{array}{l}\text { Voltage_0 } \\
\text { (Detected } \\
\text { Amplitude) }\end{array}$ & 0.0013 & 4.87 & vata & 0.0011 \\
\hline $\begin{array}{l}\text { Voltage_0 } \\
\text { (Detected } \\
\text { Frequency) }\end{array}$ & 76 & 85 & & \\
\hline & Minimum & Maximum & Description & wf_increment \\
\hline $\begin{array}{l}\text { Channel } \\
\text { pitta }\end{array}$ & & & pitta & 0.0032 \\
\hline $\begin{array}{l}\text { Voltage_1 } \\
\text { (Detected } \\
\text { Amplitude) }\end{array}$ & 0.004 & 3.8 & & \\
\hline $\begin{array}{l}\text { Voltage_1 } \\
\text { (Detected }\end{array}$ & 67 & 72 & & \\
\hline
\end{tabular}




\begin{tabular}{|l|l|l|l|l|}
\hline Frequency) & & & & \\
\hline & & & & \\
\hline $\begin{array}{l}\text { Channel } \\
\text { kapha }\end{array}$ & Minimum & Maximum & Description & $\begin{array}{l}\text { min } \\
\text { wf_increment }\end{array}$ \\
\hline $\begin{array}{l}\text { Voltage_2 } \\
\text { Detected } \\
\text { Amplitude) }\end{array}$ & 0.0085 & 4.1 & kapha & 0.0021 \\
\hline $\begin{array}{l}\text { Voltage_2 } \\
\text { (Detected } \\
\text { Frequency) }\end{array}$ & 61 & 68 & & \\
\hline
\end{tabular}

\section{RESULTS}

The results were taken from 20 persons for three filters. These results were recorded in the morning, afternoon and evening. The pulses that were recorded in the evening and morning were bit slower than that recorded in the afternoon i.e. for one subject the pulse rate in the morning and evening was $73 \mathrm{~Hz}$ and $75 \mathrm{~Hz}$ whereas in the afternoon it was $77 \mathrm{~Hz}$.

Out of these 20 people, three subjects were suffering from bradycardia and two subjects from tachycardia. The waveforms of tachycardia and bradycardia are shown below. In Table 5, the maximum frequency that was recorded in the vata waveforms of the person is $102 \mathrm{~Hz}$ which is greater than $100 \mathrm{~Hz}$ and the minimum waveform increment is 0.53 volts which is greater than 0.5 volts. Hence the subject is suffering from Tachycardia. In Table 6, the minimum frequency that was recorded in the kapha waveforms of the person is $39 \mathrm{~Hz}$ which is less than $40 \mathrm{~Hz}$ and the minimum waveform increment is 0.19 volts which is less than 0.5 volts. Hence the subject is suffering from Bradycardia.

Table 5: Results of Tachycardia recorded

\begin{tabular}{|l|l|l|l|l|}
\hline $\begin{array}{l}\text { Channel } \\
\text { vata }\end{array}$ & Minimum & Maximum & Description & $\begin{array}{l}\text { min } \\
\text { wf_increment }\end{array}$ \\
\hline $\begin{array}{l}\text { Voltage_0 } \\
\text { (Detected } \\
\text { Amplitude) }\end{array}$ & 0.67 & 4.87 & vata & 0.53 \\
\hline $\begin{array}{l}\text { Voltage_0 } \\
\text { (Detected } \\
\text { Frequency) }\end{array}$ & 85 & 102 & & \\
\hline
\end{tabular}

Table 6: Results of Bradycardia recorded

\begin{tabular}{|l|l|l|l|l|}
\hline $\begin{array}{l}\text { Channel } \\
\text { kapha }\end{array}$ & Minimum & Maximum & Description & $\begin{array}{l}\text { min } \\
\text { wf_increment }\end{array}$ \\
\hline $\begin{array}{l}\text { Voltage_2 } \\
\text { (Detected } \\
\text { Amplitude) }\end{array}$ & 0.21 & 3.5 & kapha & 0.19 \\
\hline $\begin{array}{l}\text { Voltage_2 } \\
\text { (Detected } \\
\text { Frequency) }\end{array}$ & 39 & 41 & & \\
\hline
\end{tabular}

\section{CONCLUSION}

The results from different filter VIs were compared for selecting the most appropriate filter. The comparison results of different filters are shown in the tables below. Table 7 shows the comparison of the filters for Channel 0 i.e. Vata Prakruti. The minimum waveforms increment column shows the minimum and feasible changes in the values of the waveforms. After the analysis the increments in the High Pass filter was found to be more feasible and practical for the observations of waveforms. Table 8 shows the comparison of the filters for Channel 1 i.e. Pitta Prakruti. Table 9 shows the comparison of the filters for Channel 2 i.e. Kapha Prakruti.

Table 7: Filter Results Comparison for vata (Channel 0)
\begin{tabular}{|l|l|l|l|l|}
\hline & $\begin{array}{l}\text { Frequen } \\
\text { cy }\end{array}$ & $\begin{array}{l}\text { Minimu } \\
\mathbf{m}\end{array}$ & $\begin{array}{l}\text { Maximu } \\
\mathbf{m}\end{array}$ & $\begin{array}{l}\text { min } \\
\text { wf_increm } \\
\text { ent }\end{array}$ \\
\hline $\begin{array}{l}\text { Smoothi } \\
\text { ng Filter }\end{array}$ & 73 & 0.00054 & 3.9 & 0.00017 \\
\hline $\begin{array}{l}\text { High } \\
\text { pass } \\
\text { Filter }\end{array}$ & 79 & 0.38 & 4.6 & 0.23 \\
\hline $\begin{array}{l}\text { Low } \\
\text { Pass } \\
\text { Filter }\end{array}$ & 82 & 0.0075 & 4.8 & 0.0026 \\
\hline
\end{tabular}

Table 8: Filter Results Comparison for pitta (Channel 1)

\begin{tabular}{|l|l|l|l|l|}
\hline & $\begin{array}{l}\text { Frequen } \\
\text { cy }\end{array}$ & $\begin{array}{l}\text { Minimu } \\
\mathbf{m}\end{array}$ & $\begin{array}{l}\text { Maximu } \\
\mathbf{m}\end{array}$ & $\begin{array}{l}\text { min } \\
\text { wf_increm } \\
\text { ent }\end{array}$ \\
\hline $\begin{array}{l}\text { Smoothi } \\
\text { ng Filter }\end{array}$ & 67 & 0.00063 & 4.3 & 0.00038 \\
\hline $\begin{array}{l}\text { High } \\
\text { pass } \\
\text { Filter }\end{array}$ & 73 & 0.42 & 3.8 & 0.13 \\
\hline $\begin{array}{l}\text { Low } \\
\text { Pass } \\
\text { Filter }\end{array}$ & 77 & 0.0086 & 4.1 & 0.0035 \\
\hline
\end{tabular}

Table 9: Filter Results Comparison for kapha (Channel 2)

\begin{tabular}{|l|l|l|l|l|}
\hline & $\begin{array}{l}\text { Frequen } \\
\text { cy }\end{array}$ & $\begin{array}{l}\text { Minimu } \\
\mathbf{m}\end{array}$ & $\begin{array}{l}\text { Maximu } \\
\mathbf{m}\end{array}$ & $\begin{array}{l}\text { min } \\
\text { wf_increm } \\
\text { ent }\end{array}$ \\
\hline $\begin{array}{l}\text { Smoothi } \\
\text { ng Filter }\end{array}$ & 77 & 0.00073 & 4.2 & 0.00048 \\
\hline $\begin{array}{l}\text { High } \\
\text { pass } \\
\text { Filter }\end{array}$ & 58 & 0.35 & 3.9 & 0.19 \\
\hline $\begin{array}{l}\text { Low } \\
\text { Pass } \\
\text { Filter }\end{array}$ & 65 & 0.0091 & 3.6 & 0.0024 \\
\hline
\end{tabular}

Similar results were observed in the database when the system was tested on 20 different persons by using these three filters. The high pass filter has proved to be the most consistent and appropriate filter for the system. The waveforms of the subjects recorded in the morning are the weakest, slightly stronger in the evening and strongest in the afternoon. The prakruti prediction is done accurately and the heart diseases like Tachycardia and Bradycardia are diagnosed properly.

\section{REFERENCES}


[1] Harsha Godhia, Yasmin Hazrat, Shashank Kabra, Mita Bhowmick, Pulse Wave Detection And Analysis.

[2] Peng Wang, Wangmeng Zuo, A Compound Pressure Signal Acquisition System for Multichannel Wrist Pulse Signal Analysis IEEE TRANSACTIONS, 6, JUNE 2014.

[3] L. Xu, K. Wang, D. Zhang, Y. Li, Z. Wan, J. wang, "Objectifying Researches on Traditional Chinese Pulse Diagnosis" Informatica Medica Slovenica, 2009.

[4] Prasad Joshi, Rohin Daruwala, Investigations into TIM perspective of Radial Pulse Analysis (IEEE January, 2013).

[5] Bhaskar Thakker, and Anoop Lal Vyas, Outlier Pulse Detection and Feature Extraction for Wrist Pulse Analysis, World Academy of Science, Engineering and Technology Vol: 3 2009-07-25.

[6] Xiao Chen, Pulse Signal Acquisition Based on LabView Software, (IEEE 2012).

[7] M.Sharmila Begum, Diagnosing Diseases Through Pulse Using Pressure Sensor 978-1-4673- 2149-5/12/ (C2012 IEEE).

[8] Peng Wang, Wangmeng Zuo, Hongzhi Zhang, Design and Implementation of a Multi Channel Pulse Signal Acquisition System, 2012 5th International Conference on Biomedical Engineering and Informatics (BMEI 2012).

[9] Jug-Man Hwang, Jung-Min Park, and Seong-Dok Park, Memkr, Wrist-Located Pulse Detection using IR Reflection due to Pulse Added Volume of Arterial Blood, 2004 International Conference on Computational Electromagnetics.

[10] Chung-Shing Hu, Yu-Feng Chung, Ching-Hsing Lu, Pulse Differences and 3D Pulse Mapping in TPNI Displacements, 978-1-4577-2168-7/11@2013 IEEE.

[11] Peng Wang, Hongzhi Zhang, Wangmeng Zuo, David Zhang, A Comparison of Three Types of Pulse Signals: Physical Meaning and Diagnosis Performance 2013 6th International Conference on Biomedical Engineering and Informatics (BMEI 2013).

[12] Prasad Joshi, Rohin Daruwala, Objective Evaluation of Radial Pulse Signal, 2013 IEEE.

[13] Jayaraj Joseph, V Jayashankar, A Virtual Instrument for Real Time in vivo Measurement of Carotid Artery Compliance, 30th Annual International IEEE EMBS Conference 2008

[14] "Pulse based sensor design for wrist pulse signal analysis and health diagnosis", Krittika Goyal, Ravinder Agarwal, Biomedical Research 2017; 28 (12): 5187-5195. 